\title{
GAMBARAN PENALARAN MORAL PADA REMAJA YANG TINGGAL DI DAERAH KONFLIK
}

\author{
Solvia Karina Tarigan dan Ade Rahmawati Siregar \\ Universitas Sumatera Utara
}

\begin{abstract}
ABSTRAK
Penelitian ini merupakan penelitian kuantitatif deskriptif yang bertujuan untuk melihat gambaran penalaran moral pada remaja yang tinggal di daerah konflik. Penelitian ini dilakukan pada 56 orang remaja yang tinggal di daerah konflik di Kelurahan Belawan 1 Kecamatan Medan Belawan, Sumatera Utara. Pengambilan sampel dilakukan dengan teknik simple random sampling. Alat ukur pada penelitian ini adalah Defining Issue Test (DIT) versi pendek. Dari hasil analisa diperoleh bahwa 31 orang berada pada tahap 4 dan 21 orang pada tahap 3 yang artinya 52 orang subjek berada pada tingkat konvensional di mana pada tingkat ini orientasinya pada otoritas hukum dan ketertiban sosial dengan ditandai adanya konformitas dengan teman sebaya. Keterhambatan perkembangan penalaran moral pada subjek dipengaruhi oleh lingkungan tempat tinggal.
\end{abstract}

Kata-kata kunci: Penalaran moral, remaja, daerah konflik

\section{DESCRIPTION OF MORAL REASONING DEVELOPMENT AMONG ADOLESCENTS LIVING IN CONFLICT AREA}

\begin{abstract}
The present research is a quantitative descriptive research aimed to describe the moral reasoning development of adolescents living in conflict areas. The research involved 56 adolescents that lives in the conflict area of Belawan 1, Medan Belawan District, North Sumatera. They were selected through a simple random sampling procedure. The measurement used for this research was a short version of the Defining Issue Test (DIT), which was constructed based on Kohlberg moral reasoning levels. The results of the study showed the participants are generally in the conventional level of Kohlberg's moral reasoning level of development, characterized by their orientation on law authority and social order, as well as conformity with peers. We conclude that the environment of which the participants is currently living hampered the development of their moral reasoning capability.
\end{abstract}

Keywords: Moral reasoning, adolescents, conflict area

Remaja merupakan bagian dari penduduk Indonesia, angkanya pada saat ini mencapai 43.548.576 orang dari penduduk Indonesia (BPS, 2010). Jumlah ini tidak kecil, maka diperlukan perhatian yang cukup besar karena remaja merupakan generasi penerus bangsa. Pada kenyatannya, banyak remaja yang justru menjadi penghambat perkembangan bangsa ini melalui beberapa tindakan kriminal, seperti terlibat dalam pengedaran narkoba ataupun terlibat dalam perkelahian pelajar. Jumlah perkelahian pelajar yang terjadi dari tahun ke tahun pun terus meningkat. Hal ini yang menyebabkan jumlah korban dari setiap terjadinya bentrokan juga terus bertambah

Salah satu tugas perkembangan yang harus dijalani oleh remaja adalah mempelajari hal-hal yang diharapkan oleh kelompok dan kemudian mau membentuk perilakunya agar sesuai dengan harapan lingkungan sosialnya tanpa terus dibimbing, diawasi, didorong dan diancam hukuman seperti yang dialami pada masa kanak-kanak. Pada masa remaja, moral merupakan suatu hal yang penting sebagai pedoman atau petunjuk bagi remaja dalam rangka mencari jalannya sendiri untuk menuju pada kepribadian yang matang dan menghindarkan diri dari konflik-konflik peran yang selalu terjadi pada masa remaja (Sarwono, 2010).

Remaja tidak lagi terfokus pada fakta yang bersifat konkrit tetapi sudah mampu mempertimbangkan berbagai kemungkinan yang ada. Remaja juga belajar bahwa peraturan diciptakan dan dipertahankan berdasarkan persetujuan sosial dan pengaplikasikannya bersifat 
relatif bagi setiap orang maupun situasi (Rice, 1993).

Furter (1965) menambahkan moral merupakan masalah yang penting dalam masa remaja. Proses perkembangan yang terjadi dalam diri seorang remaja terbentuk dengan apa yang dialami dan diterimanya selama masa anak-anak, sedikit demi sedikit hal tersebut akan mempengaruhi perkembangannya yang akan menuju dewasa. Masalah moral merupakan salah satu aspek penting yang perlu di tumbuh kembangkan dalam diri seseorang.

Penalaran moral berkenaan dengan jawaban atas pertanyaan mengapa dan bagaimana seseorang sampai pada keputusan bahwa sesuatu dianggap baik dan buruk (Sarwono, 2010). Penalaran moral berperan penting bagi pengembangan prinsip moral. Pada penalaran moral diharapkan seorang remaja yang menghadapi dilema-dilema moral secara reflektif mengembangkan prinsip-prinsip moral pribadi yang dapat bertindak sesuai dasar moral yang diyakini dan bukan merupakan tekanan sosial. Penalaran moral yang seperti ini dapat terbentuk karena penerimaan nilai moral yang diperoleh melalui lingkungan sosial, seperti: keluarga, sekolah, dan kelompok agama yang diproses melalui penalaran dan dicamkan dalam batin.

Penalaran moral terjadi dalam dan melalui interaksi individu itu sendiri dengan seluruh kondisi sosial kehidupannya. Kohlberg (1995) memandang seluruh proses perkembangan moral sebagai urutan tahap atau sejumlah ekuilibrasi yang merupakan berbagai logika moral yang kurang lebih komprehensif, yang mana tahap-tahap yang satu secara logis perlu menyusul tahap sebelumnya dan bahwa tidak satupun dapat diloncati ( dalam Duska \& Wheelan, 1982)

Penalaran moral remaja banyak dipengaruhi oleh lingkungan dimana ia hidup. Tanpa masyarakat (lingkungan), aspek moral remaja tidak dapat berkembang. Nilai-nilai moral yang dimiliki remaja lebih merupakan sesuatu yang diperoleh dari luar. Remaja belajar dan diajar oleh lingkungannya mengenai bagaimana ia harus bertingkah laku yang baik dan tingkahlaku yang bagaimana yang dikatakan salah atau tidak baik. Lingkungan ini dapat berarti orangtua, saudara-saudara, teman-teman, guru-guru dan sebagainya (Gunarsa \& Gunarsa, 2003).

Konflik perkelahian antar warga di daerah kelurahan Belawan 1 kecamatan Medan Belawan sudah sejak lama terjadi sejak tahun 1960-an. Menurut penuturan seorang warga yang sudah sejak 40 tahun yang lalu tinggal di daerah ini mengatakan hingga saat ini hal yang menjadi pemicu utama dalam konflik ini belum diketahui secara pasti. Peristiwa konflik perkelahian warga antar lingkungan terjadi berulangulang dan terus berlanjut. Konflik yang terjadi melibatkan warga di beberapa lingkungan daerah yang tinggalnya berdekatan. Daerah-daerah ini dihubungkan oleh daerah pemakaman umum Belawan. Menurut keterangan dari beberapa warga yang berhasil diwawancarai mereka tidak tahu secara jelasi apa yang menjadi penyebab utama yang mengawali konflik antarwarga ini. Ada juga keterangan yang di dapat dari warga yang tinggal di sekitar daerah konflik mengatakan bahwa konflik terjadi disebabkan oleh perebutan penguasaan lahan parkir di sekitar taman pemakaman yang merupakan sumber mata pencaharian sebagian besar warga disekitar taman pemakaman.

Penanggulangan yang dilakukan belum juga tuntas, terutama masalah perdamaian antara pihak-pihak yang bertikai. Hasil wawancara yang dilakukan kepada Kapolsek Medan Belawan bahwa setiap minggu beliau mengirimkan 10 personil untuk menjaga kawasan yang terdiri dari 28 lingkungan tersebut, dan menitikkan personil dari kepolisian pada 5 daerah yang rawan terjadinya perkelahian atau konflik warga antar lingkungan tersebut. Setiap hari pihak kepolisian 
Medan Belawan melakukan apel (upacara) setiap pagi di lingkungan yang rawan konflik tersebut. secara letaknya, 5 wilayah yang sering terjadi konflik ini hanya dibatasi oleh tempat pemakaman umum (TPU) yang menjadi batas wilayah daerahdaerah tersebut.

Kapolsek juga menambahkan konflik sosial antar lingkungan ini seringkali dipicu oleh masalah sepele dan kesalah fahaman. Dicontohkannya, konflik yang dipicu oleh perkelahian antar anak remaja dalam permainan sepak bola. Selain itu, ketersinggungan yang terjadi ketika saling mengejek oleh anak-anak. Hal-hal seperti ini lah yang sering mengacu perkelahian dilingkungan ini. Lapisan masyarakat yang terlibat bukan hanya pada kalangan orang dewasa, remaja bahkan anak usia 5 tahun pun ikut larut ke dalam perkelahian yang terjadi. tidak ketinggalan juga kaum ibu-ibunya.

Berdasarkan penjelasan di atas maka hal ini yang membuat peneliti tertarik untuk meneliti penalaran moral pada remaja yang tinggal di daerah konflik antar warga karena seperti yang dijelaskan di atas bahwa penalaran moral dibentuk oleh lingkungan sekitar individu tersebut.

\section{METODE}

Metode penelitian merupakan unsur penting dalam sebuah penelitian ilmiah sehingga metode yang digunakan dalam penelitian dapat menentukan apakah hasil penelitian tersebut dapat dipertanggung jawabkan (Hadi, 2002). Metode yang digunakan dalam penelitian ini metode kuantitatif yang bersifat dekriptif yang dimaksud untuk melihat bagaimana gambaran perkembangan penalaran moral remaja yang tinggal di daerah konflik antar warga di Kelurahan Belawan 1 Kecamatan Medan Belawan, Sumatera Utara.

\section{Populasi dan sampel}

Populasi di dalam penelitian ini adalah remaja yang tinggal di daerah konflik. Mengingat keterbatasan peneliti untuk menjangkau keseluruhan populasi, maka peneliti hanya meneliti sebagian dari keseluruhan populasi yang dijadikan sebagai subjek penelitian, atau yang dikenal dengan nama sampel. Sampel dari penelitian ini remaja yang tinggal di daerah konflik di Kelurahan Belawan 1 Kecamatan Medan Belawan.

Ciri-ciri atau karakteristik dari sampel penelitian ini adalah :

1) Tinggal di daerah Kelurahan Belawan 1

Penelitian ini dilakukan di Kelurahan Belawan 1 karena daerah ini merupakan daerah terjadinya konflik antarwarga.

2) Berusia 18-21 tahun

Dalam penelitian ini peneliti menggunakan karakterisik subjek yang termasuk kepada kelompok remaja akhir karena pada masa ini individu dapat melihat sistem sosial secara keseluruhan. Remaja sudah memilih prinsip moral untuk hidup. Individu melakukan tingkah laku moral yang dikendalikan oleh tanggung jawab batin sendiri (Monks, 2002).

3) Pendidikan SMP-SMA

Pada penelitian ini menggunskan subjek yang tingkat pendidikannya SMP sampai dengan SMA hal ini karena menurut Supeni (dalam Muslimin, 2004) menyatakan bahwa faktor pendidikan merupakan salah satu faktor yang mempengaruhi perkembangan penalaran moral. Dalam hal ini remaja yang tinggal di daerah Kelurahan Belawan 1 mayoritas tingkat pendidikannya SMP sampai dengan SMA.

Teknik sampel yang akan digunakan dalam penelitian ini adalah simple random sampling. Menurut Mustafa (2002), simple random sampling adalah cara atau teknik yang dapat dilakukan jika analisis penelitian 
cenderung deskriptif dan bersifat umum. Perbedaan karakter yang mungkin ada pada setiap unsur atau elemen populasi bukan hal yang penting bagi rencana analisisnya. Dengan demikian setiap unsur populasi harus mempunyai kesempatan yang sama untuk bisa dipilih menjadi sampel.

Adapun penggunaan teknik simple random sampling dalam penelitian ini diawali dengan mendata jumlah seluruh remaja dari beberapa lingkungan di Kelurahan Belawan 1 yang rentang usianya 18 sampai 21 tahun. Setelah didapatkan hasil jumlah keseluruhan maka dipilihlah secara acak sebanyak 60 orang remaja sebagai subjek dalam penelitian ini. Namun, hanya 56 orang saja yang bersedia untuk berpartisipasi.

\section{Variabel dan alat ukur}

\section{Definisi operasional penalaran moral}

\begin{tabular}{cllr}
\multicolumn{2}{c}{ Penalaran } & moral adalah \\
kemampuan yang & dimiliki & seorang
\end{tabular} individu untuk melakukan penilaian terhadap perilaku yang baik atau buruk, timbul dari dalam diri, bukan karena paksaan dari luar, yang disertai dengan tanggung jawab. Tahap penalaran moral dalam penelitian ini mengacu pada tahapan penalaran moral yang dikemukakan oleh Köhlberg (1995).

Penalaran moral diukur dengan menggunakan Defining Issues Test (DIT) versi pendek (Rest,1979) yang telah diadaptasi ke dalam bahasa Indonesia. Defining Issues Test (DIT) versi pendek merupakan tes tertulis yang menyediakan tiga permasalahan moral bagi subjek dalam bentuk cerita, dimana setiap cerita diikuti dengan 12 pernyataan. Setiap pernyataan ini mencerminkan suatu tahap perkembangan moral tertentu.

Penalaran moral dalam penelitian ini ditunjukkan melalui nilai $\mathrm{P}$ dari test DIT (Defining Issues Test). Rentang nilai $\mathrm{P}$ dari 0-95 dimana Nilai $\mathrm{P}$ (principle morality) yang merupakan penilaian relative (relative impertance) subjek tentang pertimbangan prinsip moral dalam menghadapi suatu dilema moral, diperoleh dari penjumlahan nilai yang diperoleh subjek untuk tahap 5A, 5B, dan 6. Tahap $5 \mathrm{~A}, 5 \mathrm{~B}$, dan 6 berhubungan dengan morality of sosial contract, morality of intuitive humanism dan morality of principle of idea social cooperation. Semakin tinggi nilai $\mathrm{P}$ menunjukkan semakin tinggi penalaran moral. Sebaliknya, semakin rendah nilai $P$ menunjukkan semakin rendah penalaran moral.

\section{Alat ukur}

Alat ukur merupakan metode pengumpulan data dalam kegiatan penelitian yang mempunyai tujuan untuk mengungkap fakta mengenai variabel yang diteliti (Hadi, 2000). Alat ukur yang digunakan dalam penlitian ini adalah Defining issues test (DIT) yang dikembangakan oleh Rest (1979). Alat ukur ini bertujuan untuk melihat bagaimana pandangan seseorang dalam menyelesaikan suatu situasi yang mengandung dilema moral. DIT merupakan suatu tes pilihan berganda yang bersifat objektif, disusun berdasarkan teori perkembangan moral dari Kohlberg. Saat ini telah ada dua versi, yaitu DIT-1 dan DIT-2. Dalam penelitian ini digunakan DIT-1 bentuk pendek (short form)

DIT-1 terdiri dari 3 buah cerita dilema sosial yang menyangkut moral, masing-masing disertai dengan 12 pertanyaan. Setiap pertanyaan ini mencerminkan suatu tahapan perkembangan moral tertntu atau tipe penalaran moral tertentu. Untuk setiap pernyataan subjek harus memilih salah satu pertimbangan dari lima pertimbangan yang ada, yaitu : sangat penting, penting, agak penting, kurang pening, dan tidak penting. Langkah selanjutnya adalah menentukan urutan (ranking), pertanyaan mana yang menurut subjek merupakan pernyataan terpenting pertama, terpenting kedua, terpenting ketiga, dan terpenting keempat. 
Pada intinya, tahap yang ditampilkan dalam DIT mengikuti tahap perkembangan penalaran moral dari Kohlberg, tetapi Rest tidak menggunakan urutan yang sama persis. Dalam DIT urutan yang digunakan adalah tahap 2, 3, 4, 5A, 5B dan 6. Tahap 5A dan tahap 5B merupakan penjabaran dari tahap 5 Kohlberg. Tahap 1 tidak digunakan dalam DIT karena Rest tidak menggunakan anak kecil sebagai subjek penelitian dalam menyusun DIT. Hasil akhir tes tidak meletakkan seseorang pada tahap perkembangan tertentu, tapi menghasilkan skor kuantitatif yang menunjukkan kemampuan yang lebih dalam memahami dan menetapkan prinsip moral abstrak, dalam bentuk indeks $\mathrm{P}$ (0-95). Indeks $\mathrm{P}$ diperoleh dengan menjumlahkan skor berdasarkan prinsip, yaitu pada tahap 5A, 5B dan 6 (Rest, 1979).

\section{Validitas dan reliabilitas}

Setiap penelitian diharapkan dapat memperoleh hasil yang benar-benar obyektif, yaitu penelitian tersebut dapat menggambarkan keadaan yang sebenarnya dari masalah yang diteliti. Suatu alat ukur dapat dikatakan valid apabila alat ukur tersebut mempunyai ketepatan atau kecermatan dalam melakukan fungsi ukurnya dan memberikan hasil ukur yang sesuai dengan maksud dilakukannya pengukuran tersebut (Azwar, 2001). Oleh karena itu alat ukur yang digunakan harus memiliki validitas dan reliabilitas sebagai alat ukur.

Berdasarkan penelitian yang dilakukan Rest (1979), reliabilitas tes DIT menunjukkan koefisien 0,44 hingga 0,92. Koefisien validitasnya adalah 0,68 . Skala Pengungkap Pendapat Tentang MasalahMasalah Sosial telah digunakan oleh Pratidarmanastiti (1991) pada siswa SMA se-Yogyakarta dalam penelitiannya dan didapatkan $\mathrm{rtt}=0,830$, yang berarti tes ini dapat diandalkan.

Aspek-aspek yang dikembangkan dalam Defining Issue Test (DIT) seperti pada Tabel 1.
Tabel 1 Aspek yang dikembangkan dalam Defining Issue Test (DIT)

\begin{tabular}{cl}
\hline No & \multicolumn{3}{c}{ Aspek } \\
\hline 1. & $\begin{array}{l}\text { Menimbang kekuatan relatif akan sistem } \\
\text { nilai yang berkompetisi didalam suatu } \\
\text { situasi }\end{array}$ \\
2. & $\begin{array}{l}\text { Memperhitungkan apa yang harus } \\
\text { dilakukan seseorang dalam suatu situasi }\end{array}$ \\
atas dasar prioritas pertimbangan tertentu \\
Merumuskan rencana tindakan atas dasar \\
system nilai yang relevan
\end{tabular}

\section{HASIL}

Hasil penelitian pada subjek remaja yang tinggal di daerah konflik sebanyak 56 orang menunjukkan bahwa remaja yang tinggal di daerah konflik yang berada pada tahap penalaran moral tahap 2 sebanyak 1 orang $(1,78 \%)$, sebanyak 21 orang $(37,5 \%)$ subjek yang berada pada tahap 3, 31 orang $(55,36 \%)$ berada pada tahap 4 , sebanyak 2 orang $(3,58 \%)$ berada pada tahap 5A, pada tahap 5B tidak ada subjek penelitian yang berada pada tahap ini, dan subjek yang berada pada tahap 6 sebanyak 1 orang $(1,78 \%)$. Dari hasil di atas dapat di lihat bahwa penalaran moral pada remaja yang tinggal di daerah konflik yang menjadi subjek dalam penelitian ini paling banyak berada pada tahap 4 yaitu sebesar 31 orang subjek (55,36\%). Pada tahap ini merupakan tahap yang berorientasi pada otoritas hukum dan ketertiban sosial dimana dalam tahap ini perilaku yang baik ditunjukkan dengan menuruti harapan kelompok sosial yang ditandai dengan adanya konformitas pada lingkungan sosial, mendukung serta membenarkan seluruh aturan dari kelompok sosial (Kohlberg, 1995). Hal ini sejalan dengan hasil wawancara dengan remaja yang tinggal di daerah Kelurahan Belawan 1 yang menyatakan bahwa aksi perkelahian yang dilakukan seringkali hanya berdasarkan ajakan dari teman-teman sebaya. Ketika mereka menolak ajakan untuk tidak ikut dalam aksi perkelahian mereka akan dianggap tidak memiliki rasa solidaritas dan kebersamaan bahkan bisa sampai dikucilkan oleh teman-teman sebayanya. 
Pada tingkat penalaran moral prakonvensional sebanyak 1 orang subjek $(1,78 \%)$, pada tingkat penalaran moral konvensional sebanyak 52 orang subjejk $(92,86 \%)$, dan pada tingkat penalaran moral pascakonvensional sebanyak 3 orang subjek $(5,36 \%)$. Dari hasil diatas maka dapat dilihat bahwa tingkat penalaran moral pada remaja yang tinggal di daerah konflik yang menjadi subjek dalam penelitian ini paling banyak berada pada tingkatan konvensional yaitu sebanyak 52 orang subjek (92,86\%). Kohlberg (1995) menyatakan, di usia remaja seorang remaja harus mencapai tahap perkembangan moral ketiga, yaitu moralitas

pascakonvensional (postconventional morality) (Hurlock 1980).

\section{DISKUSI}

Pada tingkatan pascakonvensional terdapat usaha yang jelas untuk merumuskan nilai dan prinsip moral yang diterapkan terlepas dari otoritas kelompok yang bersifat universal (Kohlberg, 1995). Hal ini tidak tergambarkan pada remaja yang tinggal di Daerah Kelurahan Belawan 1 dimana para remaja di daerah ini masih sebatas berkonformitas dengan lingkungan sosialnya, sesuai dengan tingkat konvensional (Kohlberg, 1995). Mereka belum sampai merumuskan atau melakukan penilaian terhadap prinsip moral yang diterapkan oleh otoritas kelompok sosialnya.

Dari penjelasan di atas dapat diartikan bahwa remaja yang tinggal di daerah konflik di Kelurahan Belawan 1 terhambat perkembangan penalaran moralnya. Hal ini sejalan dengan pendapat Duska dan Whelan (1982) menyatakan bahwa mutu lingkungan sosial mempunyai pengaruh yang signifikan kepada cepatnya perkembangan penalaran moral dan tingkatan perkembangan yang dicapai seseorang. Dengan demikian dapat disimpulkan bahwa lingkungan tempat tinggal remaja yang menjadi subjek dalam penelitian ini memiliki pengaruh yang besar dalam perkembangan penalaran moral remaja yang tinggal di daerah konflik.

Berdasarkan jenis kelamin pada subjek laki-laki paling banyak berada pada tahap penalaran moral tahap 4 dengan jumlah subjek sebanyak 15 orang subjek dan pada subjek perempuan paling banyak berada pada tahap penalaran moral tahap 4 dengan jumlah subjek 16 orang subjek.

Berdasarkan usia, subjek yang berusia 18 tahun paling banyak berada pada tahap penalaran moral pada tahap 4 yaitu sebanyak 18 orang subjek. Pada subjek yang berusia 19 tahun paling banyak berada pada tahap penalaran moral tahap 4 yaitu sebanyak 6 orang subjek. Pada subjek yang berusia 20 tahun paling banyak berada pada tahap penalaran moral pada tahap 3 yaitu sebanyak 8 orang subjek. Dan pada subjek yang berusia 21 tahun paling banyak berada pada tahap penalaran moral tahap 3 dan 4 yaitu dengan jumlah masing-masing 4 orang subjek. Dari data diatas dapat disimpulkan bahwa usia seseorang tidak ditentukan oleh usianya hal ini sesuai dengan pendapat Kohlberg (dalam Martani, 1995) perkembangan moral itu tidak ditentukan oleh usia kronologis. Setiap orang mempunyai kecepatan perkembangan yang berbeda. Jadi sangat dimungkinkan

orang dengan usia yang sama memiliki tahap penalaran moral yang berbeda.

Faktor yang juga dapat mempengaruhi penalaran moral adalah peran orang tua (Hurlock, 1980). Berdasarkan status tempat tinggal subjek yang tinggal bersama dengan orangtua paling banyak berada pada tahap penalaran moral tahap 4 yaitu sebanyak 27 orang subjek dan subjek yang tidak tinggal bersama orangtua paling banyak berada pada tahap penalaran moral tahap 3 dan 4 dengan masing masing berjumlah 4 orang subjek. Kohlberg (dalam Janssens \& Geris, 1992) memandang bahwa pengaruh utama dari keluarga adalah pada diskusi antara 
orangtua dengan anak mengenai nilai-nilai dan norma, dari pada pengalaman anak sendiri akan disiplin, hukuman, dan hadiah dari orangtua.

Menurut Kohlberg (1995), faktor lain yang dapat mempengaruhi inkonsistensi antara penalaran moral dan perilaku moral yaitu faktor situasional, motivasional, emosional, dan ketahanan ego (ego strength). Artinya dalam situasi yang berbeda, seseorang dapat menghasilkan perilaku moral yang berbeda pula. Dengan demikian para remaja yang tinggal di daerah konflik dapat melakukan perbuatan yang tidak mencerminkan tahap penalaran moralnya hal ini dapat disebabkan karena faktor situasional dimana daerah tempat mereka tinggal adalah daerah yang situasinya sering terjadinya konflik antarwarga.

\section{Kesimpulan}

Setelah dilakukan pengolahan dan analisis data, maka diperoleh kesimpulan penelitian sebagai berikut:

1) Dari hasil penelitian diperoleh gambaran dari 56 orang subjek paling banyak berada pada tahap 4 yaitu sebanyak 31 orang subjek $(55,36 \%)$ dimana pada tahap ini merupakan tahap yang berorientasi pada otoritas hukum dan ketertiban sosial dimana dalam tahap ini perilaku yang baik ditunjukkan dengan menuruti harapan kelompok sosial yang ditandai dengan adanya konformitas pada lingkungan sosial, mendukung serta membenarkan seluruh aturan dari kelompok sosial (Kohlberg, 1995).

2) Berdasarkan tingkat penalaran moral diperoleh gambaran dari 56 orang subjek paling banyak berada pada tingkat konvensional dengan jumlah sebanyak 52 orang subjek $(92,86 \%)$.

3) Hasil gambaran tingkat penalaran moral pada subjek dalam penelitian ini menunjukkan sebanyak 1 orang $(1,78 \%)$ subjek penelitian yang berada pada tingkat prakonvensional, sebanyak 52 orang $(92,86 \%)$ subjek penelitian berada pada tingkat konvensional, dan sebanyak 3 orang $(5,36 \%)$ subjek penelitian berada pada tingkat pascakonvensional.

4) Berdasarkan jenis kelamin subjek penelitian laki-laki dan perempuan masing-masing paling banyak berada pada tahap penalaran moral tahap 4 . Berdasarkan usia subjek penelitian dengan usia 18 tahun paling banyak berada pada tahap penalaran moral tahap 4, usia 19 tahun paling banyak pada tahap 4, usia 20 tahun paling banyak pada tahap 3 serta usia 21 tahun paling banyak berada pada tahap 3 dan 4. Berdasarkan tingkat pendidikan subjek yang pendidikannya SMP paling banyak berada pada tahap penalaralan moral tahap 4 dan subjek yang pendidikannya SMA paling banyak berada pada tahap penalaran moral tahap 3. Serta berdasarkan status tempat tinggal, subjek yang tinggal bersama dengan orangtua paling banyak berada pada tahap penalaran moral tahap 4 dan subjek yang tidak tinggal bersama dengan orangtua paling banyak berada pada tahap penalaran moral tahap 3 dan 4.

\section{Saran}

Berdasarkan penelitian yang telah dilakukan dan kesimpulan yang dikemukakan, maka peneliti mengemukakan beberapa saran yang diharapkan dapat berguna bagi perkembangan kelanjutan studi ilmiah.

\section{Saran metodologis}

1) Bagi peneliti selanjutnya yang hendak meneliti tentang penalaran moral, disarankan melakukan penelitian mengenai penalaran moral dengan karakteristik subjek yang berbeda seperti subjek yang tinggal di daerah batas Negara.

2) Bagi peneliti yang tertarik untuk meneliti tentang penalaran moral disarankan untuk menggunakan faktor lain yang turut mempengaruhi 
perkembangan penalaran moral seperti faktor budaya, gender atau sosialekonomi.

\section{Saran praktis}

1) Bagi orangtua

Saran yang dapat diberikan kepada orang tua secara umum, adalah Orang tua dapat menstimulasi perkembangan penalaran moral remaja dengan memberikan perhatian yang lebih tentang seperti apa seharusnya seorang remaja dalam hal perilaku yang mencerminkan penalaran moral yang sesuai sebagai seorang remaja yang beranjak menjadi dewasa.

2) Bagi Remaja

Penalaran moral pada remaja masih banyak yang berada pada tahap konvensional. Peningkatan penalaran moral menuju tahap yang lebih tinggi bisa dilakukan dengan memperbanyak pengetahuan tentang moral misalnya dengan cara berdiskusi tentang moral dengan remaja yang telah mencapai tahap pascakonvensional.

3) Bagi Pemerintahan Setempat

Bagi Pemerintah setempat khususnya tingkat Kelurahan maupun Kecamatan dapat membuat suatu program pembinaan dimana tujuan dari program ini untuk dapat mempengaruhi perkembangan moral yang sekaligus juga dapat mengurangi tingkat konflik yang sering terjadi akibat dipicu oleh kenakalan para remaja yang tinggal di daerah ini.

\section{REFERENSI}

Atkinson, R.L., Atkinson, R.C., Hilgard, E.R. (1999). Pengantar Psikologi Jilid II. Jakarta : Erlangga

Azwar, S. 1(997). Metode Penelitian. Yogyakarta: Pustaka Pelajar

Azwar, S. (2001). Reliabilitas dan Validitas. Yogyakarta: Pustaka Pelajar

Azwar, S. (2003). Penyusunan Skala Psikologi. Yogyakarta: Pustaka Pelajar
Azwar, S. (2007). Penyusunan Skala Psikologi. Yogyakarta: Pustaka Pelajar

Badan Pusat Statistik (BPS). (2010). [online] diakses tanggal 13 Oktober 2011

http://www.bps.go.id/tab_sub/view.php

?kat=1\&tabel=1\&daftar=1\&id_sub yek $=12 \&$ notab $=1$

Bertens, K. (1993). Etika. Jakarta : Gramedia Pustaka Utama

Bull, N.J. (1970). Moral Judgment From Childhood To Adolescene. London: Routledege \& Kegan Paul.

Daradjad, Z. (1983). Kesehatan Mental. Jakarta: Gramedia Pustaka Utama

Duska R., dan Whelan M. (1982). Perkembangan Moral: Perkenalan dengan Piaget dan Kohlberg, Terjemahan Dwija Atmaka, Yogyakarta: Kanisius.

Gunarsa, S.D., Gunarsa, Y.S.D. (1992). Psikologi Perkembangan Anak \& Remaja. Jakarta: Gunung Mulia

Gunarsa, S.D., Gunarsa, Y.S.D., 2003. Psikologi Perkembangan Anak \& Remaja. Jakarta: Gunung Mulia

Hadi, S. 2000. Statistik II. Yogyakarta: Andi Offset

Hasan, A. B. P. (2006). Psikologi Perkembangan Islami: Menyingkap Rentang Kehidupan Manusia dari Prakelahiran hingga Pascakematian. Jakarta : PT. RajaGrafindo Persada.

Hurlock, E.B. 1990. Psikologi Perkembangan. Edisi 6. Jilid 2. Alih Bahasa

Meitasari Tjandrasa. Jakarta: Erlangga

Hurlock, E. B. 1999. Psikologi Perkembangan. Suatu Pendekatan Sepanjang

Rentang Kehidupan. Edisi 5. Alih Bahasa Istiwidayanti \& Soedjarwo. Jakarta: Erlangga 
Janssens, J., Geris, J. (1992). Child Rearing : Influence on prosocial and Moral Development. Netherlands: University of Nijmegen.

Jersild, A. T. (1975) Psychology of adolescence. London: The MacmilanCompany

Jones, R.N (1996). Effective Thinking Skills. Los Angeles: SAGE Publications Ltd

Kaplan, L. E. (2006). Moral Reasoning of MSW Social Workers and TheInfluence of Education. Journal of Social Work Education. 42 (3), 507522.

Kartono, K. 2001. Psikologi Remaja. Jakarta: CV Rajawali

Köhlberg, L. 1995. Tahap-Tahap Perkembangan Moral (alih Bahasa: John de Santo dan Agus Cremmers). Yogyakarta: Kanisius

Kompas. (2010). Tawuran pelajar tak kunjung surut. [online]. Diakses 15 Oktober 2011

http://megapolitan.kompas.com/read/2 011/10/21/02385365/Tawuran.Pelajar.

Tak.Kunjung.Surut

Mardiya. 2005. Menyoal Penyalahgunaan Obat Terlarang Oleh Remaja. Artikel

[On-line] ww.kilonprogokab.go.

id/v21/getfile.php?file=Menyoal...Obat ..di akses 10 Februari 2012

Martani, W. (1995). Perkembangan Penalaran Moral pada Remaja yang Berbeda Latar Belakang Budaya. Jurnal Psikologi, 2, 14-20.

Monks, F.J.- A.M.P. Knoers, Siti Rahayu Haditono. 2002. Psikologi Perkembangan Pengantar Dalam Berbagai Bagiannya. Yogyakarta: Gajah Mada University Press

Muslimin, I. Z. (2004). Penalaran Moral pada siswa SLTP Umum dan Madrasah Tsanawiyah. Humanitas : Indonesian Psychological Journal Vol. 1 No. 2, hal, 25 -32. Yogyakarta : Universitas Wangsa manggala.

Mussen, P.H dkk. 1994. Perkembangan dan Kepribadian Anak. Jakarta:Arcan

Mustafa, H. 2000. Teknik Sampling. [online] diakses 15 Januari 2012 http://home.unpar.ac.id/ hasan/SAMP LING.doc.

Papalia, D. E., Olds, S. W., \& Feldman, R. D. (2001). Human Development

(8th edition). New York: Mc. Graw-Hill Companies, Inc.

Pickering, Peg. (2000) "How To Manage Conflict". USA : National Press Publication, USA

Pratidarmanastiti, L. 1991. Perkembangan Moral Remaja Delinkuen Dan Non Delinkuen. Tesis (tidak diterbitkan). Yogyakarta: Fakultas Psikologi Universitas Gajah Mada

Rest, J. R. (1979). Revised Manual for The Defining Issues Test. USA: Mineapolis Minnesota Moral Research Projects.

Santrock, JW. 2002. Life-Span Development Jilid 2. Jakarta: Erlangga

Sari, T.Y (2011). Hubungan Keharmonisan Keluarga dengan Penalaran Moral pada Remaja Delikuen. Skripsi. Medan: Universitas Sumatera Utara

Sarwono, S.W. 2002. Psikologi Remaja. Cetakan ke-3. Edisi I. Jakarta: PT Raya Grafindo Persada

Setiono, K. 1982. Perkembangan Penalaran Moral Tinjauan dari Sudut Pandang Teori Sosio-Kognitif. Jurnal Psikologi Dan Masyarakat. No. 2

Sidney Siegel (1992), Statistik non Parametrik. Jakarta: Gramedia

Soekanto, Soerjono (1990). Sosiologi Suatu Pengantar, Jakarta: Rajawali Pers.

Susan, N. 2010. Pengantar Sosiologi Konflik dan Isu-Isu Konflik Kontemporer. Jakarta: Kencana Prenada Group 
Suseno, F.M. 1987. Etika Dasar MasalahMasalah Pokok Filsafat Moral. Yogyakarta: Kanisius

Tambunan, Raymond. (2001). Tawuran Antar Remaja. [Online]. Diakses 7 Agustus $2011 \quad$ http://www.epsikologi.com/remaja/161001.htm

Waraheni, P.A. (2006). Sikap Remaja Terhadap Perilaku Seks Bebas Ditinjau Dari Tingkat Penalaran Moralpada Siswa Kelas Dua Sma Kesatrian 1 Semarang. Skripsi. Semarang: Universitas Negeri Semarang. 